\title{
THE RELATIONS BETWEEN INNOVATIVENESS, MARKET ORIENTATION AND SUCCESS AMONG INDUSTRIAL FIRMS IN POLAND
}

The main goal of this article is to analyze the relations in medium-sized and large industrial firms in Poland between the innovativeness, market orientation and success. In order to achieve this aim, a model of the dependencies between these factors is presented, together with an assessment of the significance and influence of innovation and market orientation on the success of a firm. We consider the activities of firms in the fields of product innovation, process innovation, marketing innovation and organizational innovation, in accordance with The Oslo Manual: Guidelines for Collecting and Interpreting Innovation Data.. The qualitative concept of the success of a firm is used in place of the performance of a firm in strict economic terms. This study was carried out based on data from 7,267 mediumsized and large industrial firms active in Poland. The main conclusion of the article is that the path from product and process innovation to success arrives through organizational and marketing innovations. A firm's market orientation is an important factor in determining its success. However, at the same time it exhibits a weak, negative influence on innovation in the fields of organizational and marketing innovation. This apparent contradiction results from the fact that in Poland the marketing orientation of a firm may depend on the activities of those in the sales department, rather than on the formal structure of this department. Moreover, such a market orientation (which depends on the individual approaches of employees) may counteract the motivation to create a costly formal system which would promote the market orientation of a firm. model

Keywords: innovation, market orientation, success, industrial firms, structural equation

JEL Classifications: D22, L21, L60

DOI: 10.15611 aoe.2018.1.12

\section{INTRODUCTION}

A quarter of a century has passed since the change in Poland's economic system, which fundamentally changed the rules of economic competition and the relations between firms and their clients. The introduction of a market economy, together with the inflow of foreign investment and

\footnotetext{
${ }^{*}$ WSB University in Wrocław.

** Opole University of Technology.
} 
restructuring of Polish firms, has undoubtedly led to a change in the market orientation of firms and their activities aimed towards future success, including innovation. The starting point of this research is based on the following questions: has, in the course of the last 25 years, the management of Polish firms created systems for realizing innovation processes; are they integrated with the market orientation of a firm, and what effect do these two factors have on the success of a firm? It is reasonable to assume that such changes must have occurred, due to both the increasing competition and training within firms that are based in other market economies, but have factories within Poland.

This article analyzes the relations of technological (process and product) innovation, as well as organizational and marketing innovation, and market orientation with the success of a firm. The main goal is to establish a model of the interdependencies between innovativeness, market orientation and success in a sample of industrial firms in Poland. The study was based on data from 7267 medium-sized and large industrial firms active in Poland. These data come from the PNT-02 report from the Polish Central Statistical Office ("Questionnaire on innovations in industry", the complete version). In order to analyze the relations between the variables considered, the approach of structural equation modelling was used.

\section{THE INFLUENCE OF MARKET ORIENTATION ON THE SUCCESS OF A FIRM AND INNOVATION}

The concept of the market orientation of a firm, introduced by Kohli and Jaworski (1990), has become an important research tool (see also Narver, Slater, 1990a, 1990b; Tuominen, Möller, 1996). Market orientation is based on sensitivity to signals from the market. It is a management philosophy, as well as a set of activities and behaviours (Küster, Vila, 2011). Market orientation is associated with implementing the marketing concept of a firm and is present when a firm systematically applies this concept in its activities. (Moreira, Silva, 2013). Narver and Slater (1990b) define market orientation as the organizational culture best encouraging behaviour which creates added value for clients and, in this way, improves the effectiveness of a firm. From this perspective, the main components of market orientation are: client orientation, reacting to competition, and coordination between functional groups within a firm.

From a behavioural perspective, the main components of market orientation are: knowledge creation in the firm as a whole (creating a system 
for recognizing the present and future needs of clients), transmitting this information to all the internal units of a firm and reacting to this information, aiding all departments to find effective answers to the needs of the market (Kohli, Jaworski, 1990). It may be assumed that the level of importance of activities and strategies which are de facto market-driven indicates the degree to which a firm is market orientated.

Hurley and Hult (1998) show that high-tech firms which show a high level of market orientation behaviour (MOB) clearly gain better results from their innovation processes. Han, Kim and Sirvastava (1998), as well as Lado and Maydeu-Olivares (2001), obtain similar results. The research on firms in the USA and EU carried out by the latter pair of authors mentioned above show that the more market orientated a firm is, the more innovative it tends to be. In addition, Liao, Chang, Wu and Katrichis (2011), Tajeddini, Trueman and Larsen (2006), Kirca, Jayachandran and Bearden (2005), Lukas and Ferrell (2000), together with Grinstein (2008), found a positive association between market orientation and innovativeness.

Han, Kim and Sirvastava (1998), as well as Lukas and Ferrell (2000), indicate the important influence of market orientation on product innovation. Han, Kim and Sirvastava (1998) obtained similar results for the influence of market innovation on organizational innovation. It seems necessary to consider the potential effect of market orientation on various types of innovativeness, taking into account the possibility of synergy. Hence, we consider the following hypotheses:

H1: market orientation has a significant, positive influence on product and process innovation.

H2: market orientation has a significant influence on organizational and marketing innovation.

The influence of market orientation on the success of a firm has been the subject of much research (Fritz, Mundorf, 1994; Hooley et al., 2000; Langerak, 2001; Shoham, Rose, 2001; Harris, 2001; Homburg, Pflessor, 2000; Hult et al., 2003; Langerak, 2003; Cano, et al., 2004; Zhuo et al., 2005; Mavondo et al., 2005; Hult et al., 2005). The positive influence of market orientation on the results of a firm have been noted in e.g. Rose (2001), Harris (2001), Homburg and Pflessor (2000); Hult, Snow, and Kandemir (2003). However, some research indicates that market orientation has no significant influence on the results of a firm (Chan, Ellis, 1998; Gray et al., 1998, Harris, 2001; Langerak, 2003). It can be hypothesized that the relation between market orientation and success may be moderated by other variables (Han, et al., 1998; Homburg, Pflesser, 2001; Ellis, 2006). On the 
basis of a meta-analysis of results from 28 countries (56 studies), Ellis (2006) stated that market orientation is a determining factor for the results of a firm, but the strength of this association depends on cultural traits, the country's economic policies, as well as the size and the maturity of a market.

One conclusion that is important for the present study is the following: among firms active in Slovenia, which like Poland is a transitional economy, market orientation leads to increased sales and customer loyalty via innovation and reputation (Snoj et al., 2007).

Mavondo, Chimhanzi and Stewart (2005) state that market-oriented firms are simultaneously more innovative, which leads to better performance. In effect, such firms are improving their competitiveness (Kim, Pennings, 2009). Han, Kim and Sirvastava (1998) obtained similar results. Hence, we may formulate the following hypotheses:

H3: market orientation has a significant, positive influence on the success of a firm via product and process innovation.

H4: market orientation has a significant, positive influence on the success of a firm via marketing and organizational innovation.

H5: market orientation has a significant, positive and direct influence on the success of a firm.

\section{THE INFLUENCE OF INNOVATIVENESS ON THE RESULTS ACHIEVED BY A FIRM}

Present knowledge does not allow us to unequivocally state that innovativeness gives better financial results. In their research on American high-tech firms, Im and Workman (2004) indicate that the ability to introduce new products in conjunction with a marketing orientation is the key to success. The positive influence of organizational innovation on results has been stated by e.g. Darroch (2005), Ho (2011), Hui, Radzi, Jenatabadi, Kasim and Radu (2013). Based on an analysis of 187 U.S. firms, Calantone, Cavusgil and Zhao (2002) stated that competitiveness is not only based on technological development, but also on understanding the needs of clients and the behaviour of competitors. Atalay, Anafarta and Sarvan (2013) analyzed results from 113 firms working in the motor industry in Turkey. They showed that product and process innovations have a significant and positive influence on a firm's results. At the same time, they found no significant association between the marketing and organizational innovations of a firm and its results. Since innovations ensure a competitive edge in many international and global markets, for international firms investing in 
them is a critical factor in increasing their profits (Asakawa, Som 2008). Based on analyzing the data from British firms, it can be stated that the influence of innovation on market value is greater for firms with higher market shares. Also, firms with large market shares introduce technological innovations as a form of protection. Strong competition between firms undoubtedly requires firms to be innovative (Blundell et al., 1999).

Geroski (1995) studied the influence of major innovations and patents on many performance measures, such as profitability, stock market rates of return and corporate growth. Only a weak direct influence of innovation on these measures was observed. Hence, the gains from innovativeness tend to be indirect. On the other hand, it was found that innovative firms are less sensitive to any decline in market conditions. One reason for innovativeness only having an indirect influence on the economic success of a firm lies in the fact that innovations mean that clients are faced with new, as yet untried, products. The good impression created by previous products may become blurred (Walsh et al., 2009).

If, as argued, the influence of innovations on results is of an indirect nature, then using the concept of the success of a firm may illustrate the nature of the relation between innovativeness and the results obtained by a firm. The concept of the success of a firm appears in e.g. Llonch and Waliño (1996), as well as Aaker (1998). Küster and Vila (2007) define the success of a firm in terms of three factors. The first factor is business results which comprise of four elements: sales margin, net profit, profitability and global results. The second factor is given by external performance indicators regarding customer satisfaction and loyalty. The third factor refers to internal performance indicators and covers elements related to brand image and reputation, perceived quality, manager and employee training, innovation exit rate and company efficiency.

Evangelista and Vezzani (2012) underline that multidimensional innovation strategies involving all four types of innovation: product, process, marketing and organizational) have the biggest impact on the economic results of a firm, whereas the least effective innovation strategies involve just product innovations or just process innovations.

On the basis of the above, one may formulate the following hypotheses:

H6: technological (product and process) innovation has a significant, positive influence on the success of a firm via marketing and organisational innovation.

H7: technological (product and process) innovation has a significant, positive and direct influence on the success of a firm. 


\section{THE INFLUENCE OF INNOVATIVENESS ON THE SUCCESS OF A FIRM}

In the author's opinion it is necessary to show that the components of the concept of the success of a firm considered here (ability to gain new markets in various countries, attracting a skilled workforce, brand image and reputation) are influenced by innovativeness. Hence, this section considers the results of various articles on these relations. The hypothesis of the influence of innovativeness on financial results seems justified by the arguments made above.

\subsection{Influence of innovativeness on the workforce}

Not only are the skills of the workforce related to innovativeness, but also innovativeness enables and stimulates a firm to be based on well-paid, highly skilled employees. This can be seen based on the example of the skiing industry in Europe, in which the innovations and the rate at which they are implemented, are major drivers of the competitiveness of a firm. Producing skis in developing Asian countries is not a realistic option. This stimulates production and development in countries with high labour costs (Caskey, 2014).

Coad (2009) states that product innovations are associated with an increase in employment, whereas process innovations may lead to a decrease in employment.

Good employee management influences the level of innovation (DíazDíaz et al., 2012; Oke et al., 2012). Hence, if there exists a positive association (direct or indirect) between the level of innovation and economic results, then more economically successful firms can afford to employ a highly skilled workforce and successfully attract such workers. Hence, the ease with which firms attract a skilled workforce should be an indicator of the innovativeness of a firm and its success.

\subsection{The influence of innovativeness on market share}

Laforet (2010) states that present market leaders (whose market shares are particularly high) are not only characterised by their visionary growth strategies, but also concentrate on being innovative. Evangelista and Vezzani (2012) state that innovative firms grow at a faster rate than non-innovative firms and increase their market share at the expense of such firms. As a 
result, they have a greater production capacity which leads to increased employment and level of skills in the workforce. Firms which compete on the basis of low costs/prices often have a falling level of skills in their workforce.

In their research on the B2B medical sector, Falkenreck and Wagner (2011) find that the perceived innovativeness of a service provider is associated with the perceived value of such services, customer satisfaction (CS) and corporate reputation (CR). As a result, the reputation of a firm may lead to it having a competitive edge in the increasing market for B2B medical services.

The introduction of new, innovative products in the consumer packagedgoods sector is a tool in the fight for market share with so called own-brand labels, i.e. with brands which are owned by the retailer or distributor and are only sold in the retailer's/distributor's own outlets. It has been stated that where there is an increased number of newly introduced innovative products, the market share of own-brand labels is lower (Kumar, Steenkamp, 2007; Martos-Partal, 2012).

Research by Banbury and Mitchell (1995) shows that incumbent firms which regularly introduce incremental innovations have a larger market share, while the introduction of new products which simply follow the innovations of competitors have a very weak influence on market share. This research was carried out on firms producing cardiac pacemakers. New, innovative products are introduced even at the cost of the sales of other goods that the firm produces. The introduction of such innovations has an indirect positive effect on the long-term success of a firm via an increase in market share.

In the global LCD industry, which is active in Poland, it has been found that technological changes are strongly correlated with market share. Process innovation, together with an increase in technological capability, leads to an increased market share (Lee, Kim, 2013).

In recent years, innovative business models based on a high profile on the Internet have enabled smaller firms to increase their market share and successfully compete with larger players in the market (Amabile, 2007).

\subsection{The influence of innovativeness on brands and goodwill}

Innovativeness is stated as one of the priorities of the Lisbon Strategy, as well as the "Europe 2020" strategy. However, introducing innovativeness in transitional countries (e.g. in Poland, Hungary, Romania) can be problematic 
(Markowska, Strahl, 2012; Szewczyk, Łobos, 2012; Świadek, 2010). Studies (e.g. Hooley et al., 2004) have indicated the low level of resources promoting innovativeness in these countries compared to highly developed countries (Austria, Ireland, the UK). In the author's opinion, the importance of corporate reputation is also neglected in transitional countries, compared to highly developed countries.

The study by Martin, Gollan and Grigg (2011) highlights the mutual relations between building an employer's brand, innovativeness and the reputation of a firm. They can form a virtuous circle in which a positive brand image attracts a skilled workforce which is capable of creating and introducing new innovations, which in turn strengthens brand image.

Jensen (1992) shows that the positive reception of the new product of a firm producing a wide range of goods may positively influence the sales of other goods in this range by increasing the firm's reputation as an innovator.

Nowadays firms can obtain a competitive edge in the field of corporate reputation by introducing innovations based on a clear understanding of ecological and social issues (so-called green innovations; Hillestad et al., 2010).

\subsection{The influence of innovativeness on market development and internationalizing a firm's activities}

The results of studies show that, in the medium and long term, innovativeness accelerates the process of a firm's internationalization (see Altomonte et al., 2013). The sample for their study was a set of production firms from a number of EU countries. Innovativeness and internationalization are particularly strongly associated in the case of new technologybased firms (Onetti et al., 2012). Both of these processes are driven by the search for new knowledge, which knows no boundaries and is conditioned by the existence of various social and inter-organizational ties across the globe (Doz et al., 2001; Gereffi, Korzeniewicz, 1994; Powell et al., 2005; Schweizer, 2005).

Kumar, Mudambi and Gray (2013) state that an increasing number of firms from emerging markets have gained a prominent position due to the interaction of the so called "three I" factors (3I) - innovativeness, internationalization and institutions, which support the functioning of a liberal market economy.

Filippetti (2011) states that among European firms one may notice a form of feedback: innovative firms are more competitive in the international 
market and, simultaneously, internationalization leads to greater innovativeness. Osuna (2014) makes similar conclusions regarding the interdependdency of innovativeness and internationalization.

\section{DATA AND METHODS}

The goal of this article is to derive a model which gives an overview of the interdependencies between innovation, market orientation and success in a sample of industrial firms. The analysis is based on data from 7,267 medium-sized and large firms active in Poland. These data were obtained from the PNT-02 report of the Polish Central Statistical Office (GUS), "Questionnaire on innovations in industry" covering the period 2010-2012. This study covered all industrial firms employing at least 50 workers (complete study). According to the Polish Classification of Business Activity in 2007 (PKD 2007 ${ }^{1}$ ), industry covers the following sectors: B - mining and quarrying, C - manufacturing, D - electricity, gas, steam and air conditioning supply, E - water supply; sewerage, waste management and remediation activities. Of the 7,267 firms considered: 150 were in sector B, 6,631 in sector C, 259 in sector D, and 587 in sector E.

The PNT-02 questionnaire relates to innovative activities within firms, in particular new and significantly improved products and processes, as well as newly introduced organizational and marketing methods. It is based on an international questionnaire formulated by experts from the EU and OECD (The Harmonized Survey Questionnaire). The study based on the PNT-02 questionnaire was carried out within the framework of the international research project Community Innovation Survey (CIS 2012), which was coordinated by Eurostat.

In order to test the hypotheses regarding the relationships between the variables considered, structural equation modelling was adopted (Bollen, 1989; Kline, 2011; Schinka and Velicer, 2003). In order to estimate the parameters involved in the model and assess its goodness of fit, the SEPATH module of the STATISTICA package was used. All the numerical calculations based on the numerical data were carried out in the Wrockaw Statistical Office.

\footnotetext{
1 The Polish Classification of Business Activities 2007 (PKD 2007) was based on the Statistical Classification of Economic Activities in the European Union-NACE Rev. 2.
} 


\section{MEASUREMENT OF SUCCESS}

In the present study, there were no possible means for measuring objectively the success of a firm in terms of the concepts presented in the literature and in Table 1 (due to the data available in the GUS database).

Table 1

Measures of market orientation and success - definition in the literature vs. concepts used in this study

\begin{tabular}{|c|c|c|}
\hline Specification & Market orientation & Success \\
\hline $\begin{array}{l}\text { Definition in } \\
\text { the literature }\end{array}$ & $\begin{array}{l}\text { Attitudes related to market } \\
\text { orientation (Llonch, 1993; Dawes, } \\
\text { Faulkner and Sharp, 1998) } \\
\text { Seven-level Likert scale, where } 1= \\
\text { Totally disagree, and } 7 \text { = Totally } \\
\text { agree } \\
\text { 1.Great importance is attached to } \\
\text { analyzing customer needs and } \\
\text { tastes } \\
\text { 2.There is interest in responding to } \\
\text { customer needs and tastes } \\
\text { 3.Customer satisfaction and } \\
\text { product profitability is closely } \\
\text { monitored } \\
\text { 4.Efforts focus on the long term } \\
\text { 5.There is definite interest in } \\
\text { knowing what the competition is } \\
\text { doing } \\
\text { 6.Customer satisfaction is } \\
\text { monitored through after sales } \\
\text { services }\end{array}$ & $\begin{array}{l}\text { Business success (Heinen, 1996; } \\
\text { Paul, 1996; Strauss and Frost, 1999; } \\
\text { Furrer and Sudharshan, 2001; } \\
\text { Sparkes and Brychan 2001) } \\
\text { Seven-level Likert scale, where } 1 \text { = } \\
\text { Totally disagree, and } 7 \text { = Totally } \\
\text { agree } \\
\text { External performance indicators } \\
\text { 1.Customer satisfaction } \\
\text { 2.Customer loyalty } \\
\text { Internal performance indicators } \\
\text { 3.Image/reputation } \\
\text { 4.Quality } \\
\text { 5.Management training } \\
\text { 6.Implementation of innovations } \\
\text { 7.Company efficiency } \\
\text { Business results } \\
\text { 8.Sales margin } \\
\text { 9. Net profit } \\
\text { 10.Profitability } \\
\text { 11.Global results } \\
\text { 12. Growth in sales } \\
\text { 13.Achievement of objectives }\end{array}$ \\
\hline Present study & $\begin{array}{l}\text { 1.Intensification or improvements } \\
\text { in the marketing of goods and } \\
\text { services } \\
\text { 2.Increased elasticity in the } \\
\text { activities and responsiveness of a } \\
\text { firm }\end{array}$ & $\begin{array}{l}\text { 1.Relative position of the firm } \\
\text { (compared to competitors) with } \\
\text { respect to quality, customers' } \\
\text { perception of quality and brand } \\
\text { image } \\
\text { 2.Relative position of the firm in } \\
\text { terms of market share } \\
\text { 3.Attractiveness of the firm in terms } \\
\text { of gaining a highly skilled workforce } \\
\text { 4.Availability of funds } \\
\text { 5. The ability to enter new markets }\end{array}$ \\
\hline
\end{tabular}

Source: own elaboration. 
However, it should be noted that the five components described in the second row closely correspond to the components as described in the literature (listed in row one). Although the concept of success adopted in this research does not precisely correspond to the definition given in the literature, the sections devoted to a review of the literature (regarding the influence of innovativeness on market share, brand image and skills in the workforce etc.) show that innovativeness influences the measures of success adopted in this study (quality, brand image, market share, workforce, profitability, ability to enter new markets), as confirmed by the studies cited. The problem of measuring market orientation is more problematic, since only two variables from the PNT-02 survey can be taken as measures of this factor. This is presented in Table 1.

Each of the latent variables $\left(\xi_{1}\right.$ - product and process innovation, $\xi_{2}-$ organizational and marketing innovation, $\xi_{3}$ - market orientation and $\eta_{1}$ success) are measured using an appropriate set of empirical indicators. In the case of product and process innovation $\left(\xi_{1}\right)$, these are the indicators $X_{1}$ and $X_{2}$, for organizational and marketing innovation $\left(\xi_{2}\right)$ - the indicators $X_{3}$ and $X_{4}$, and for market orientation $\left(\xi_{3}\right)$ - the indicators $X_{5}$ and $X_{6}$ (see Table 2 for a definition of these indicators). In order to implicitly define "success" $\left(\eta_{1}\right)$, the subjective assessment of managers was used (the indicators $\mathrm{Y}_{1}, \mathrm{Y}_{2}, \mathrm{Y}_{3}, \mathrm{Y}_{4}$ and $\mathrm{Y}_{5}$ ).

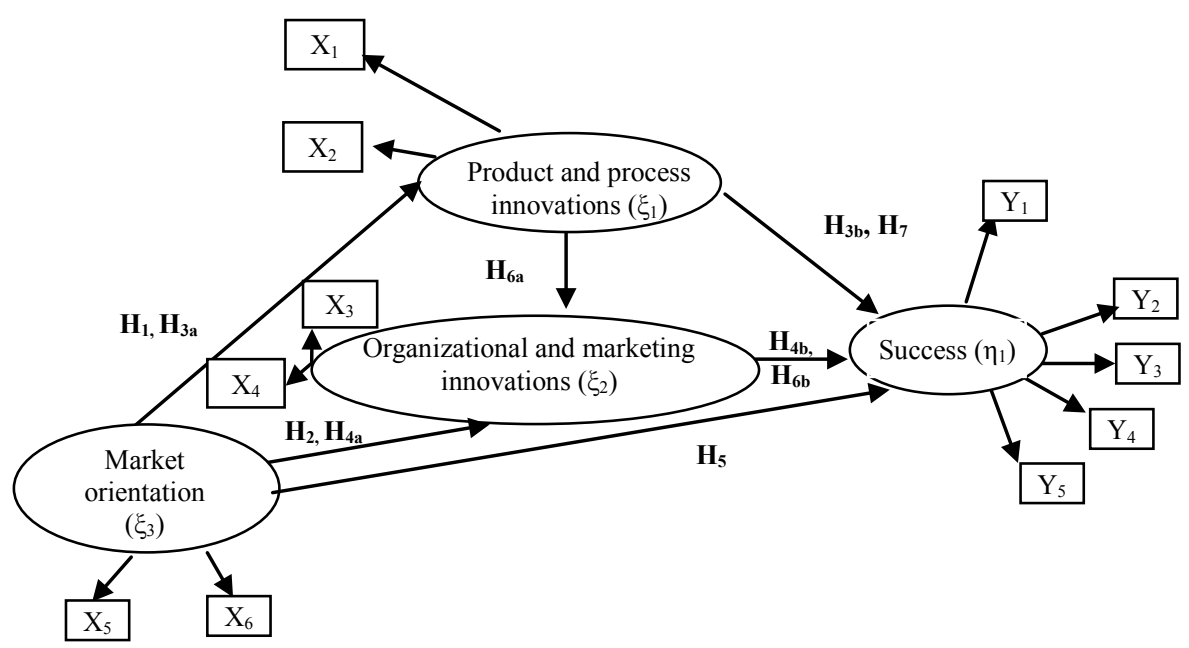

Figure 1. The theoretical model proposed (Model 1)

Source: own elaboration. 
Table 2

Specification of indicators used in the model

\begin{tabular}{l}
$\frac{1}{1}$ Indicator \\
\hline 1 \\
\hline $\mathrm{X}_{1}-$ introduction of \\
products which are new or \\
significantly improved (at \\
least from the point of \\
view of the firm)
\end{tabular}

(1)

$\mathrm{X}_{2}$ - introduction of processes which are new or significantly improved (at least from the point of view of the firm)

Definition of the indicator

The sum of the answers given to the following two questions (which gives a 3 -point scale: from 2 to 4 ).

In the years 2010-2012, did the firm introduce:

Q1. new or significantly improved (at least from the point of view of the firm) products?

Q2. new or significantly improved (at least from the point of view of the firm) services?

$1=$ No, 2 =Yes

The sum of the answers given to the following three questions (which gives a 4-point scale: from 3 to 6).

In the years 2010-2012, did the firm introduce:

Q1. new or significantly improved methods of producing goods/services?

Q2. new or significantly improved methods in the field of logistics or the distribution of goods?

Q3. new or significantly improved methods (systems) supporting the processes in your firm, such as conservation/maintenance systems, operational systems related to buying raw materials or book-keeping, and/or mathematical optimization/control systems?

$1=$ No, 2 =Yes

$\mathrm{X}_{3}$ - introduction of new methods in the firm's operational procedures, new procedures for assigning tasks and delegating decision making, new organizational procedures related to dealing with the surrounding environment - e.g. other firms or public institutions.

$\mathrm{X}_{4}$ - introduction of significant changes in the design, concept or packaging of goods, introducing new means or techniques for advertising products, introducing new methods of distribution or forming new sales channels
The sum of the answers given to the following three questions (which gives a 4-point scale: from 3 to 6 ).

In the years 2010-2012, did the firm introduce:

Q1. new procedures in the firm's operational procedures (e.g. managing deliveries, fundamental changes in the way a firm operates, "slim" production systems and/or quality control systems)?

Q2. new methods of assigning tasks and delegating decision making (e.g. introducing new systems defining employees' responsibilities, forms of teamwork, decentralization, integration or creation of departments, training systems)?

Q3. new organizational procedures related to dealing with the surrounding environment - e.g. other firms or public institutions (e.g. creating new partnerships or alliances, new forms of subcontracting tasks externally to specialist firms)?

$1=$ No, 2 =Yes

The sum of the answers given to the following four questions (which gives a 5-point scale: from 4 to 8 ).

In the years 2010-2012, did the firm introduce:

Q1 significant changes in the design, concept or packaging of goods (with the exception of changes which modify the functioning or use of the product - since such changes are defined to be product innovation)?

Q2. new means or techniques for advertising products (e.g. the first use of a medium for advertising, new image/branding, introduction of loyalty cards)?

Q3. new methods of distribution or forming new sales channels (e.g. the introduction of franchising or licensing the distribution of a product, direct sales, exclusive wholesale, new concepts for presenting products)?

Q4. new methods for calculating the prices of services and goods (e.g. introduction of a new method of varying the price of a good depending on demand, system of price reductions)?

$1=$ No, $2=$ Yes 
Table 2, cont.

\begin{tabular}{|c|c|}
\hline 1 & 2 \\
\hline $\begin{array}{l}\mathrm{X}_{5}-\text { intensifying or } \\
\text { improving the marketing } \\
\text { of goods and services }\end{array}$ & $\begin{array}{l}\text { Based on the answer to the question: } \\
\text { Of what importance was the intensification/improvement of the marketing } \\
\text { of goods and services to achieving the goals of the firm in the years } 2010 \text { - } \\
2012 \text { ? } \\
\text { A 4-point scale from } 1 \text { to } 4 \text {; scale: } 1 \text { - high, } 2 \text { - medium, } 3 \text { - low, } 4 \text { - no } \\
\text { importance }\end{array}$ \\
\hline $\begin{array}{l}\mathrm{X}_{6}-\text { improving the } \\
\text { elasticity and reactiveness } \\
\text { of the firm }\end{array}$ & $\begin{array}{l}\text { Based on the answer to the question: } \\
\text { Of what importance was improving the elasticity and reactiveness of the } \\
\text { firm to achieving its goals in the years } 2010-2012 \text { ? } \\
\text { A 4-point scale from } 1 \text { to } 4 \text {; scale: } 1 \text { - high, } 2 \text { - medium, } 3 \text {-low, } 4 \text { - no } \\
\text { importance }\end{array}$ \\
\hline $\begin{array}{l}Y_{1}-\text { relative (vs. } \\
\text { competing firms) position } \\
\text { of the firm with respect to } \\
\text { the quality of its products, } \\
\text { opinions regarding } \\
\text { products and brand image }\end{array}$ & $\begin{array}{l}\text { Based on the answer to the question: } \\
\text { How much of a barrier was strong competition regarding product quality, } \\
\text { opinions regarding products and/or brand image to achieving the goals of } \\
\text { the firm in the years } 2010-2012 \text { ? } \\
\text { A 4-point scale from } 1 \text { to } 4 \text {; scale: } 1 \text { - high, } 2 \text { - medium, } 3 \text { - low, } 4 \text { - no } \\
\text { importance }\end{array}$ \\
\hline $\begin{array}{l}Y_{2}-\text { relative position of } \\
\text { the firm with regard to } \\
\text { market share }\end{array}$ & $\begin{array}{l}\text { Based on the answer to the question: } \\
\text { How much of a barrier was the dominant position of competitors in the } \\
\text { market to achieving the goals of the firm in the years 2010-2012? } \\
\text { A 4-point scale from } 1 \text { to } 4 \text {; scale: } 1 \text { - high, } 2 \text { - medium, } 3-\text { low, } 4 \text { - no } \\
\text { importance }\end{array}$ \\
\hline $\begin{array}{l}Y_{3} \text { - attractiveness of the } \\
\text { firm in attracting skilled } \\
\text { personnel }\end{array}$ & $\begin{array}{l}\text { Based on the answer to the question: } \\
\text { How much of a barrier was a lack of skilled personnel to achieving the } \\
\text { goals of the firm in the years } 2010-2012 \text { ? } \\
\text { A 4-point scale from } 1 \text { to } 4 \text {; scale: } 1 \text { - high, } 2 \text { - medium, } 3 \text { - low, } 4 \text { - no } \\
\text { importance }\end{array}$ \\
\hline $\mathrm{Y}_{4}-$ access to funds & $\begin{array}{l}\text { Based on the answer to the question: } \\
\text { How much of a barrier was a lack of accessible funds to achieving the } \\
\text { goals of the firm in the years } 2010-2012 \text { ? } \\
\text { A 4-point scale from } 1 \text { to } 4 \text {; scale: } 1 \text { - high, } 2 \text { - medium, } 3 \text { - low, } 4 \text { - no } \\
\text { importance }\end{array}$ \\
\hline $\begin{array}{l}Y_{5}-\text { possibility of } \\
\text { entering new markets }\end{array}$ & $\begin{array}{l}\text { Based on the answer to the question: } \\
\text { How much of a barrier were the costs of entering new markets to achieving } \\
\text { the goals of the firm in the years } 2010-2012 \text { ? } \\
\text { A 4-point scale from } 1 \text { to } 4 \text {; scale: } 1 \text { - high, } 2 \text { - medium, } 3 \text { - low, } 4 \text { - no } \\
\text { importance }\end{array}$ \\
\hline
\end{tabular}

Source: own elaboration.

As the reliability coefficient values are above the acceptable value of 0.7 , the data can be taken as reliable for the further analysis (with the Cronbach's alphas ranging from 0.73 to 0.91 ; percentage of variance explained ranging from 60 to 82 ).

In order to assess the goodness of fit of the model, we used the following: the goodness-of-fit index (GFI), the adjusted goodness-of-fit index (AGFI), as well as the root mean square error of approximation (RMSEA). In general, the following values of indexes indicate a very good fit to the data: GFI and AGFI greater than 0.95 and the RMSEA below 0.08 (Raykov, Marcoulides, 2006), 
whereas acceptable values of these indexes are as follows: GFI $>0.90$, AGFI $>0.90$ and RMSEA $<0.10$ (MacCallum, Widaman, 2001). The results of the $\chi^{2}$ goodness-of-fit test are also presented. However, many researchers state that this test is very sensitive to the size of the sample, as it correctly rejects models for large sample sizes too frequently (Bentlera and Bonnet, 1980; Joreskog and Sorbom 1996, Hair et al. 2007). Tomarken and Waller (2003) describe potential problems with "well fitting" models.

\section{RESULTS AND DISCUSSION}

The choice of whether to accept or reject a model is based on the goodnessof-fit indexes (RMSEA, GFI, AGFI) and the $\chi^{2}$ test. The initial model tested (Figure 1) did not satisfy any of these criteria $\left(\chi^{2}=26885 ; \mathrm{df}=55\right.$; RMSEA $=0.151$; GFI $=0.847$; AGFI $=0.766$ ). Consequently, it was decided to consider alternative models by eliminating chosen arcs indicating directions of influence which were statistically insignificant or associated with low standardized weights. The model presented in Figure 2 satisfied the acceptance criteria $\left(\chi^{2}=2141 ; \mathrm{df}=41 ; \mathrm{RMSEA}=0.085, \mathrm{GFI}=0.948\right.$, AGFI $\left.=0.917\right)$.

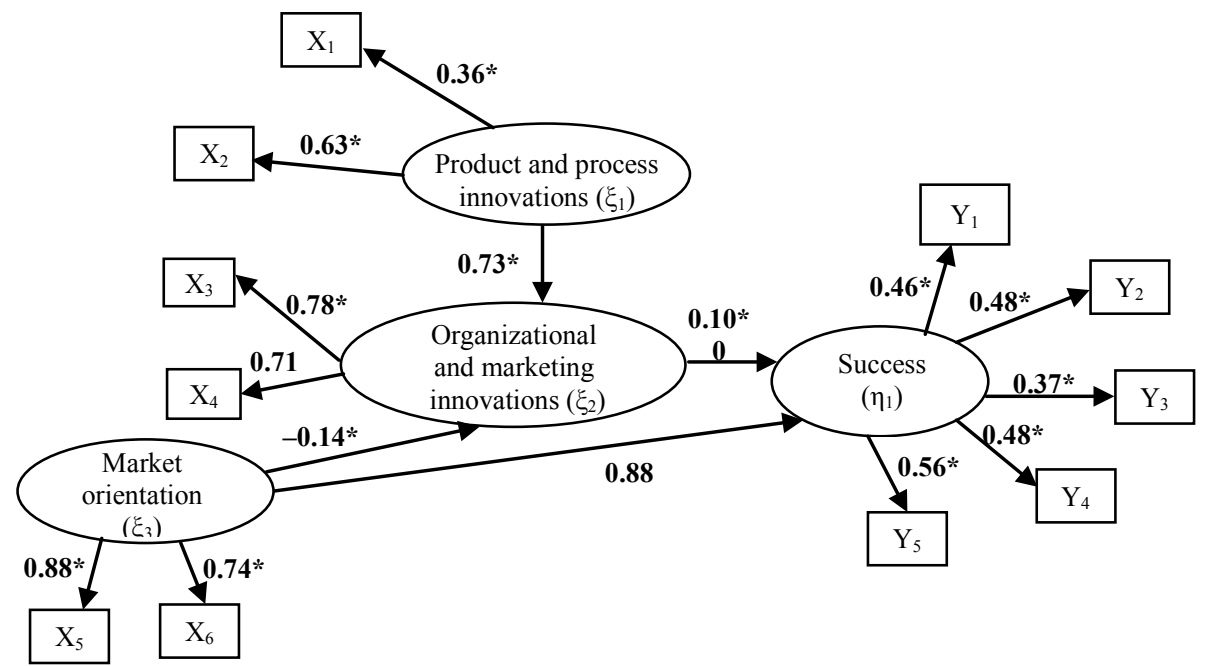

Figure 2. Results of structural equation modelling (Model 2, standardized estimates of the weights of paths, $\mathrm{N}=7267$ )

Note: Please refer to Table 2 for the names of indicators.

$\chi^{2}=2141 ; \mathrm{df}=41 ; \mathrm{RMSEA}=0.085 ; \mathrm{GFI}=0.948 ; \mathrm{AGFI}=0.917$

Source: author's calculations. 
Not all of the hypothesized associations between the variables were statistically significant. The results indicate no significant influence of the market orientation of a firm at the fundamental level of innovativeness, i.e. on product and process innovation (hypothesis $\mathrm{H}_{1}$ and hypothesis $\mathrm{H}_{3}$ ). Neither was there any significant direct influence from product and process innovation on the success of a firm (hypothesis $\mathrm{H}_{7}$ ). The influence of market orientation on organisational and marketing innovation was found to be significant (hence hypothesis $\mathrm{H}_{2}$ was confirmed), but the value of the coefficient for this arc was small and negative $(-0,14)$, indicating a weak negative influence. The results showed that organizational and marketing innovations mediated the effect of market orientation on the success, with the estimate of -0.01 (unbiased variance estimator 0.037 ).

Table 3

Estimates of the parameters (Model 2, N=7267)

\begin{tabular}{l|c|c|c|c}
\hline \multicolumn{1}{c|}{ Path } & $\begin{array}{c}\text { Standardized } \\
\text { estimate } \\
\text { of path weight }\end{array}$ & $\begin{array}{c}\text { Standard } \\
\text { deviation }\end{array}$ & t-Statistic & p-value \\
\hline Product and process innovations $\rightarrow \mathrm{X}_{1}$ & 0.36 & 0.006 & 59.993 & $\mathrm{p}<0.001$ \\
\hline Product and process innovations $\rightarrow \mathrm{X}_{2}$ & 0.63 & 0.009 & 69.732 & $\mathrm{p}<0.001$ \\
\hline $\begin{array}{l}\text { Organizational and marketing } \\
\text { innovations } \rightarrow \mathrm{X}_{3}\end{array}$ & 0.78 & 0.017 & 46.258 & $\mathrm{p}<0.001$ \\
\hline $\begin{array}{l}\text { Organizational and marketing } \\
\text { innovations } \rightarrow \mathrm{X}_{4}\end{array}$ & 0.71 & 0.000 & \multicolumn{2}{|c}{$\mathrm{N} / \mathrm{A}$} \\
\hline Market orientation $\rightarrow \mathrm{X}_{5}$ & 0.88 & 0.013 & 68.513 & $\mathrm{p}<0.001$ \\
\hline Market orientation $\rightarrow \mathrm{X}_{6}$ & 0.74 & 0.012 & 59.854 & $\mathrm{p}<0.001$ \\
\hline Success $\rightarrow \mathrm{Y}_{1}$ & 0.46 & 0.012 & 38.122 & $\mathrm{p}<0.001$ \\
\hline Success $\rightarrow \mathrm{Y}_{2}$ & 0.48 & 0.012 & 39.799 & $\mathrm{p}<0.001$ \\
\hline Success $\rightarrow \mathrm{Y}_{3}$ & 0.37 & 0.011 & 34.961 & $\mathrm{p}<0.001$ \\
\hline Success $\rightarrow \mathrm{Y}_{4}$ & 0.48 & 0.013 & 38.595 & $\mathrm{p}<0.001$ \\
\hline Success $\rightarrow \mathrm{Y}_{5}$ & 0.56 & 0.013 & 41.769 & $\mathrm{p}<0.001$ \\
\hline
\end{tabular}

N/A - Not tested for statistical significance

Source: author's calculations.

The influence of market orientation on marketing and organizational innovation (posited in $\mathrm{H} 2$ ) is negative. It may be hypothesized that the reason for this lies in the typical approach in Poland to the question of building managerial systems, which places great importance on reducing costs. On the other hand, market orientation often involves making a series of decisions leading to an increase in costs. It can be seen from publications by the Polish Central Statistical Office ( "Innovation within firms...", 2013) 
Table 4

Weights of the paths in the structural model

\begin{tabular}{|c|c|c|c|c|c|c|}
\hline Hypothesis & Path & $\begin{array}{l}\text { Standardized } \\
\text { estimate of } \\
\text { path weight }\end{array}$ & $\begin{array}{l}\text { Standard } \\
\text { deviation }\end{array}$ & t-Stat & p-value & Result \\
\hline $\mathrm{H}_{1}, \mathrm{H}_{3 \mathrm{a}}$ & $\begin{array}{l}\text { Market orientation } \rightarrow \\
\text { Product and process } \\
\text { innovations }\end{array}$ & \multicolumn{5}{|c|}{$\begin{array}{l}\mathrm{H}_{1} \text { Not supported } \\
\text { Not considered in Model } 2\end{array}$} \\
\hline $\mathrm{H}_{2}, \mathrm{H}_{4 \mathrm{a}}$ & $\begin{array}{l}\text { Market orientation } \overrightarrow{ } \\
\text { Organizational and } \\
\text { marketing innovations }\end{array}$ & -0.14 & 0.009 & -15.6 & $\mathrm{p}<0.001$ & Supported \\
\hline $\mathrm{H}_{5}$ & $\begin{array}{ll}\text { Market } \text { orientation } \rightarrow \\
\text { Success }\end{array}$ & 0.88 & 0.000 & \multicolumn{3}{|c|}{ N/A } \\
\hline $\mathrm{H}_{6 \mathrm{a}}$ & $\begin{array}{l}\text { Product and process } \\
\text { innovations } \rightarrow \text { Organi- } \\
\text { zational and marketing } \\
\text { innovations }\end{array}$ & 0.73 & 0.013 & 54.5 & $\mathrm{p}<0.001$ & Supported \\
\hline $\mathrm{H}_{4 \mathrm{~b}}, \mathrm{H}_{6 \mathrm{~b}}$ & $\begin{array}{l}\text { Organizational and mar- } \\
\text { keting innovations } \rightarrow \\
\text { Success }\end{array}$ & 0.10 & 0.024 & 4.1 & $\mathrm{p}<0.001$ & Supported \\
\hline $\mathrm{H}_{3 \mathrm{~b}}, \mathrm{H}_{7}$ & $\begin{array}{l}\text { Product and process } \\
\text { innovation } \rightarrow \text { Success }\end{array}$ & \multicolumn{5}{|c|}{$\begin{array}{l}\mathrm{H}_{7:} \text { Not supported } \\
\text { Not considered in Model } 2 \\
\end{array}$} \\
\hline
\end{tabular}

N/A - Not tested for statistical significance

Source: author's calculations.

that Polish firms clearly prefer goals which may be described as being directly connected to financial success. These goals include most prominently increasing sales and, in second place, lowering costs. The firms surveyed concentrate above all on the traditional reducing of costs of activities within the firm and at the same time are highly suspicious of cooperating with other players as a means for achieving their own goals. Thus a traditional route to efficiency emerges - concentrating on the internal functioning of the firm, combined with a mistrust of the surrounding business environment.

The negative association of market orientation with organizational and marketing innovations may not only result from the powerful orientation towards cost reduction, but also from the fact that market orientation in Polish firms is more a result of the approaches and predispositions of individual employees, together with the culture in the workplace, than the effects of a formalized system. Flexibility in relations with clients and intensification of marketing (the measures used to define market orientation) may well to a large degree reflect the everyday practices in 
sales and marketing, and the culture of working with clients rather than organizational routine or the standardization which is a component of an organizational system. Moreover, the more a firm achieves market orientation on the basis of the individual practices of employees, the less it feels the need to build a system guaranteeing such market orientation. In the environment of Polish firms, activities leading to market orientation may be highly dependent on individual employees - salespeople either have a natural disposition to work with clients or they do not. Hence, investors should pay particular attention in their choice of personnel, since these choices can have a critical impact on the functioning of the marketing or, in particular, sales division. They should seek to build a system of organizational procedures based on good practice in customer relations. In Poland, employees are still affected by the mentality of previous generations, not yet fully accepting the primacy of clients and the markets. Thus investors cannot expect that each employee will automatically assume the attitude resulting from accepting the firm's market orientation simply because they are functioning in a competitive market. Investors should thus take care that market orientation in the form of good customer relations should not just be dependent on the attitude of an employee, but be part of a formalised system within the overall organization of the firm. Many examples of firms active in Poland, e.g. commercial banks or large scale petrol suppliers, show that good customer relations can be incorporated into a system and become repeatable. We know the cases of excellent customer service systems of Orlen (petrol stations), Alior and GetIn (retail and commercial banks) or others. In this case, customer loyalty, and hence the success of an organization, will become more dependent on organizational and long-term solutions than on individual employees and their predispositions. It is also unclear whether, in the Polish environment, market orientation is associated with strong coordination between departments, as suggested by Narver and Slater (1990b). Despite significant and positive changes in the management systems used in Poland, it is still common that departments are not sufficiently integrated with each other and do not function within the framework of a single system. From the comments above, we may conclude that market orientation can take either the form of a formalized system or a non-formalized system based on the attitudes and predispositions of the employees. In a transition economy such as Poland, the second model is probably still dominant. However, investigating this is a subject for future research. 


\section{CONCLUSIONS}

This research indicates that within industrial firms active in Poland the path from product and process innovations to success leads through marketing and organizational innovations. Technological (product and process) innovation by itself does not significantly make an impact on the success of a firm. Industrial firms active in Poland should support technical innovation with marketing and organisational innovation, in order to increase the chances of attaining market success.

The results of this research supports the hypothesis that technical innovation has a weak and indirect influence on the success of a firm. This is in agreement with the conclusions made by Geroski (1995).

Market orientation is an important factor in determining the success of an organization (Fritz, Mundorf, 1994). On the other hand, it may be concluded that although market orientation leads to the success of a firm, it also connected with negative side effects (e.g. it generates costs leading to reduced profits). In the Polish environment a specific form of market orientation can be observed - market orientation based on the attitudes and dispositions of individual employees, which is not systemised. Especially from the point of view of foreign investors, this could signal the need to construct a formalized system for promoting market orientation, so that it does not completely depend on the attitudes and approaches of individual employees. This could occur, for example, in the form of organizational routines, as described by Geiger and Schroeder (2014). Many examples of behaviour by employees (and large firms) that is an undesirable inheritance of the communist system and inappropriate in a market economy can still be observed. The effects of the former system are still identifiable after 25 years of a market economy, both in the behaviour of firms and individual employees. Integration between individual departments and the introduction of standard and formal procedures, together with a focus on training, are still challenges in the environment of the transitional economy found in Poland.

\section{REFERENCES}

Aaker, D. S., Strategic Market Management. Wiley, New York, 1998.

Altomonte, C., Aquilante, T., Békés, G., Ottaviano, G. I. P., Internationalization and Innovation of Firms: Evidence and Policy, "Economic Policy”, Vol. 28, Issue 76, pp. 663-700, 2013. Amabile, S., Innovation Processes, Networks and Internet Uses: Market Growth Factors for SMES?, "Decisions Marketing", Issue 48, pp. 75-86, 2007. 
Asakawa, K., Som, A., Internationalization of $R \& D$ in China and India: Conventional Wisdom versus Reality, “Asia Pacific Journal of Management”, 25(3), pp. 375-394, 2008.

Atalay, M., Anafarta, N., Sarvan, F., The Relationship between Innovation and Firm Performance: An Empirical Evidence from Turkish Automotive Supplier Industry, "Procedia - Social and Behavioral Sciences", Vol. 75, pp. 226-235, 2013.

Banbury, C. M., Mitchell, W., The Effect of Introducing Important Incremental Innovations on Market Share and Business Survival, "Strategic Management Journal", Vol. 16, pp. 161-182, 1995.

Bentler, P. M., Bonnet, D. C., Significance Tests and Goodness of Fit in the Analysis of Covariance Structures, "Psychological Bulletin", 88 (3), pp. 588-606, 1980.

Blundell, R., Griffith, R, Van Reenen, J., Market Share, Market Value and Innovation in a Panel of British Manufacturing Firms, "Review of Economic Studies", Vol. 66 Issue 3, pp. 529-554, 1999.

Bollen, K. A., Structural Equations with Latent Variables. Wiley, New York, 1989.

Calantone, R. J., Cavusgil, S. T., Zhao, Y., Learning Orientation, Firm Innovation Capability and Firm Performance, "Industrial Marketing Management", Vol. 31 (6), pp. 515-524, 2002.

Cano, C. R., Carrillat, F. A., Jaramillo, F., A Meta-analysis of the Relationship between Market Orientation and Business Performance: Evidence from Five Continents, "International Journal of Research in Marketing", 21, pp. 179-100, 2004.

Caskey, K. R., Locating Medium Volume and Complexity Manufacturing: Cases from the Ski Industry, "Competitiveness Review", Vol. 24, Issue 2, pp. 75-94, 2014.

Chan, H. N., Ellis, P., Market Orientation and Business Performance: Some Evidence from Hong Kong, "International Marketing Review" 15, 2, pp. 119-139, 1998.

Coad, A., The Growth of Firms: A Survey of Theories and Empirical Evidence. Edward Elgar, Cheltenham, 2009.

Darroch, J., Knowledge Management, Innovation and Firm Performance, "Journal of Knowledge Management”, 9(3), pp. 101-115, 2005.

Díaz-Díaz, N. L., De Saá-Pérez, P., Novelty of Innovation and the Effect of Existing and Recently Hired R\&D Human Resources, "Innovation: Management, Policy \& Practice", Vol. 14, Issue 1, pp. 74-89, 2012.

Doz, Y. L., Santos, J., Williamson, P., From Global to Metanational: How Companies Win in the Knowledge Economy. Harvard Business School Press, Boston, MA, 2001.

Dawes, J., Faulkner, M., Sharp, B., Business Orientation Scales: Development and Psychometric Assessment, Proceedings of the 27th EMAC Conference, Track 5, pp. 461-477, Stockholm, 1998.

Działalność innowacyjna przedsiębiorstw $w$ latach 2010-2012 [Innovation within Firms in 2010-2012]. GUS, Warszawa, 2013.

Ellis, P. D., Market Orientation and Performance: A Meta-analysis and Cross-national Comparisons, "Journal of Management Studies", 43(5), pp. 1089-1107, 2006.

Europe 2020, http://ec.europa.eu/europe2020/index_en.htm

Evangelista, R., Vezzani, A., The Impact of Technological and Organizational Innovations on Employment in European Firms, "Industry Corporation Change”, 21 (4), pp. 871-899, 2012. 
Furrer, O., Sudharshan, D., The Effect of Culture on Behavioural Intentions through Service Quality Perceptions, 30th EMAC Conference, Bergen, 2001.

Falkenreck, Ch., Wagner, R., The Impact of Perceived Innovativeness on Maintaining a Buyer-seller Relationship in Health Care Markets: A Cross-cultural Study, "Journal of Marketing Management”, Vol. 27, Issue 3-4, pp. 225-242, 2011.

Filippetti, A., Frenz, M., Ietto-Gillies, G., Are Innovation and Internationalization Related? An Analysis of European Countries, "Industry \& Innovation", Vol. 18, Issue 5, pp. 437-459, 2011.

Fritz, W., Mundorf, N., Market Orientation and Corporate Success: Findings from Germany, Arbeitspapier, Technische Universität Braunschweig, Institut für Marketing, No. 94/13, 1994.

Geroski, P., Innovation and Competitive Advantage, Working Paper No. 159, 2005.

Geiger, D., Schroeder, A., Ever-Changing Routines? Toward a Revised Understanding of Organizational Routines Between Rule-Following and Rule-Breaking, "Schmalenbach Business Review", Vol. 66, Issue 2, pp. 170-190, 2014.

Gereffi, G., Korzeniewicz, M., Commodity Chains and Global Capitalism. Praeger Publishers, Westport, CT, 1994.

Gray, B., Matear, S., Boshoff, C., Matheson, P., Developing a Better Measure of Market Orientation, "European Journal of Marketing" 32, 9, pp. 884-903, 1998.

Grinstein, A., The Effect of Market Orientation and Its Components on Innovation Consequences: A Meta-analysis, "Journal of the Academy of Marketing Science", 36 (2), pp. 166-173, 2008.

Grundström, C., Sjöström, R. Uddenberg, A., Öhrwall R., Fast-growing SMEs and the Role of Innovation, "International Journal of Innovation Management", Vol. 16, No. 3, pp. 1-19, 2012.

Hair, J. F., Black, W. C. Babin, A. B., Tatham, R. L., Multivariate Data Analysis. Prentice Hal, New Jersey, 2007.

Harris, L. C., Market Orientation and Performance: Objective and Subjective Empirical Evidence from UK Companies, "Journal of Management Studies" 38, 1, pp. 17-43, 2001.

Heinen, J., Internet Marketing Practices, "Information Management \& Computer Security" 4(5), pp. 7-14, 1996.

Ho, L. A., Meditation, Learning, Organizational Innovation and Performance, "Industrial Management \& Data Systems", 111(1), pp.113-131, 2011.

Hooley, G., Cox, T, Fahy, J., Shipley, D., Market Orientation in the Transitional Economies of Central Europe: Tests of the Narver and Slater Market Orientation Scale, "Journal of Business Research", Vol. 50, pp. 273-285, 2000.

Homburg, C., Pflesser, C., A Multiple-layer Model of Market-oriented Organizational Culture: Measurement Issues and Performance Outcomes, "Journal of Marketing Research 37”, pp. 449-462, 2000.

Hult, G . T., Ketchen, D. J., Slater, S. F., Market Orientation and Performance: An Integration of Disparate Approaches, "Strategic Management Journal", 26, pp. 1173-1181, 2005 . 
Hult, G. T. M., Snow, C. C., Kandemir, D., The Role of Entrepreneurship in Building Cultural Competitiveness in Different Organizational Types, "Journal of Management", 29, 3, pp. 401-426, 2003.

Hui, H., Radzi, C., Jenatabadi, H., Kasim, F., Radu, S., The Impact of Firm Age and Size on the Relationship among Organizational Innovation, Learning, and Performance: A Moderation Analysis in Asian Food Manufacturing Companies, "Interdisciplinary Journal of Contemporary Research in Business", Vol 5, No 4, pp. 166-174, 2013.

Hillestad, T., Chunyan, X., Haugland, S. A., Innovative Corporate Social Responsibility: The Founders Role in Creating a Trustworthy Corporate Brand through "Green Innovation", "Journal of Product \& Brand Management”, Vol. 19, Issue 6, pp. 440-451, 2010.

Hooley, G. J., Beracs, J., Cadogan, J. W., Fahy, J., Fonfara, K., Gabbot, M., Kasper, H., Matear, S., Moller, K., Muhlbacher, H., Snoj, B., Theodorakis, V., Tsarenko, Y., Yau, O. H. M., Marketing Assets, Capabilities and Competitive Positioning, Proceedings of the 33nd EMAC Conference, Murcia, University Of Murcia, 2004.

Han, J. K., Kim, N., Sirvastava, R. K., Market Orientation and Organizational Performance: Is Innovation a Missing Link?, "Journal of Marketing” 62(4), pp. 30-45, 1998.

Hoyle, R. H., Structural Equation Modeling. Concepts, Issues, and Applications, Sage Publications, Inc, Thousand Oaks, 1995.

Hurley, R. F., Hult, T. M., Innovation, Market Orientation, and Organizational Learning: An Integration and Empirical Examination, "Journal of Marketing” 62(3), pp. 42-54, 1998.

Im, S., Workman, J. P., Market Orientation, Creativity, and New Product Performance in High-Technology Firms, "Journal of Marketing”, 68, pp. 114-32, 2004.

Jensen, R., Reputational Spillovers, Innovation, Licencing and Entry, "International Journal of Industrial Organization" Vol. 10, Issue 2, pp. 193-212, 1992.

Jimenez-Jimenez, D., dan Sanz-Valle, R., Innovation, Organizational Learning, and Performance, "Journal of Business Research", Vol. 64 (4), pp. 408-417, 2011.

Johnson, J. D., Meyer, M. E., Berkowitz J. M., Ethington, C. T., Miller, V. D., Testing Two Contrasting Structural Models of Innovativeness in a Contractual Network, "Human Communication Research“, 24(2), pp. 320-48, 1997.

Lopez-Nicolas, C., Merono-Cerdan, A. L., Strategic Knowledge Management, Innovation and Performance, "International Journal of Information Management", Vol 31 (6), pp. 502-509, 2011.

Jabeen, R., Alekam, J. M. E., Aldaoud, K. A. M., Mat, N. K. N., Zureigat, B. N. I., Nahi, A. K., Junaidi, A. M. F., Antecedents of Firm's Performance. Empirical Evidence from Yemeni SME's, “American Journal of Economics", Vol. 3 (1), pp. 18-22, 2013.

Joreskog, K., Sorbom, D., LISREL 8: User's Reference Guide. Scientific Software International, Chicago, 1996.

Kirca, A. H., Jayachandran, S., Bearden, W. O., Market Orientation: A Meta-analytic Review and Assessment of Its Antecedents and Impact on Performance, "Journal of Marketing", 69 (2), pp. 24-41, 2005.

Kim, H. E., Pennings, J. M., Innovation and Strategic Renewal in Mature Markets, "Organization Science", 20, pp. 368-383, 2009.

Kline, R. B., Principles and Practice of Structural Equation Modeling. The Guilford Press, New York, 2011. 
Kohli, A. K., Jaworski, B. J., Market Orientation: The Construct, Research Propositions, and Managerial Implications, "Journal of Marketing" 54, pp. 1-18, 1990.

Kumar, N., Steenkamp, J.-B. E. M., Private Label Strategy. Harvard Business School Press, Boston, 2007.

Kumar, V., Mudambi, R., Gray, S., Internationalization, Innovation and Institutions: The 3 I's Underpinning the Competitiveness of Emerging Market Firms, "Journal of International Management", Vol. 19, Issue 3, pp. 203-206, 2013.

Küster, I., Vila, N., The Market Orientation-Innovation-Success Relationship: The Role of Internationalization Strategy, "Innovation: Management, Policy \& Practice" Vol. 13, No. 1, pp. 36-54, 2011.

Küster, I., Vila, N., Medición del éxito en marketing: Propuesta desde un enfoque formativo/reflexivo, "Cuadernos Aragoneses de Economía" 17(1), pp. 235-255, 2007.

Lado, N., Maydeu-Olivares, A., Exploring the Link between Market Orientation and Innovation in the European and US Insurance Markets, "International Marketing Review", 18(2), pp. 130-145, 2001.

Laforet, S., Managing Brands - A Contemporary Perspective. McGraw-Hill Education, Maidenhead, Berkshire, 2010.

Langerak, F., Effects of Market Orientation on the Behaviours of Salespersons and Purchasers, Channel Relationship, and the Performance of Manufacturers, "International Journal of Research in Marketing”, 18, pp. 221-234, 2001.

Langerak, F., The Effect of Market Orientation on Positional Advantage and Organizational Performance, "Journal of Strategic Marketing" 11, 2, pp. 93-115, 2003.

Lee, J., Kim, B. C., The Relationship Between Innovation and Market Share: Evidence from the Global LCD Industry, "Industry \& Innovation", Vol. 20, Issue 1, pp. 1-21, 2013.

Liao, S., Chang, W., Wu, C., Katrichis, J., A Survey of Market Orientation Research (1995-2008), "Industrial Marketing Management", 40(2), pp. 301-310, 2011.

Llonch, J., Waliño, S., Efectos de la orientación al mercado en los resultados de la empresa, "Esic-Marke" t, 91(1), pp. 9-39, 1996.

Llonch, J., Orientación al mercado y competitividad de la empresa, EADA Gestión (Gestión 2000), Barcelona, 1993.

Lukas, B. A., Ferrell, O. C., The Effect of Market Orientation on Product Innovation, "Journal of the Academy of Marketing Science", 28 (2), pp. 239-247, 2000.

Markowska, M., Strahl, D., Evaluation of the European Union Regions Convergence Regarding Innovation, “Argumenta Oeconomica”, No 1 (28), pp. 41-67, 2012.

Martos-Partal, M., Innovation and the Market Share of Private Labels, "Journal of Marketing Management", Vol. 28, pp. 695-715, 2012.

MacCallum, R. C., Widaman, K. F., Preacher, K., Hong, S., Sample Size in Factor Analysis: The Role of Model Error; "Multivariate Behavioral Research", 36, pp. 611-637, 2001.

Martin, G., Gollan, P. J., Grigg, K., Is There a Bigger and Better Future for Employer Branding? Facing up to Innovation, Corporate Reputations and Wicked Problems in SHRM, "The International Journal of Human Resource Management", Vol. 22, No. 17, pp. 3618-3637, 2011. 
Moreira, C., Silva, P. M., Market Orientation, Innovation and Organizational Commitment in Industrial Firms, "Market", Vol. 25 No. 2, 2013.

Narver, J. C., Slater, S. F., Strategies for Increasing Market Orientation, Marketing Science Institute Conference, pp. 90-123, 1990a.

Narver, J. C., Slater, S. F., The Effect of a Market Orientation on Business Profitability, "Journal of Marketing" 54, pp. 20-35, 1990 b.

Oke, A., Walumbwa, F. O., Myers, A., Innovation Strategy, Human Resource Policy, and Firms' Revenue Growth: The Roles of Environmental Uncertainty and Innovation Performance, "Decision Sciences", Vol. 43 Issue 2, pp. 273-302, 2012.

Onetti, A., Zucchella, A., Jones M. V., McDougall-Covin, P. P., Internationalization, Innovation and Entrepreneurship: Business Models for New Technology-based Firms, "Journal of Management \& Governance Data", 2012.

Oslo Manual: Guidelines for Collecting and Interpreting Innovation Data, OECD, Eurostat, 2005.

Osuna, M. A. A., Innovation and Internationalization as Single Strategy of the Firm: A Unification of Theories, "International Journal of Management \& Marketing Research" (Vol. 7 Issue 1, pp. 73-84, 2014.

Paul, T., Relationship Marketing for Health Care Providers, "Journal of Health Care Marketing" 8(3), pp. 20-25, 1988.

Powell, W. W., White, D. R., Koput, K. K., Owen-Smith, J., Network Dynamics and Field Evolution: The Growth of Interorganizational Collaboration in the Life Sciences, "American Journal of Sociology", Vol. 110, pp. 1132-1205, 2005.

Raykov, T., Marcoulides, G. A., A First Course in Structural Equation Modeling, Lawrence Erlbaum Associates, NJ, 2006.

Rhee, J.. Park, T., Lee, D. H., Drivers of Innovativeness and Performance for Innovative SMEs in South Korea: Mediation of Learning Orientation, "Technovation" Vol. 30 (1), pp. 65-75, 2010

Rosenbusch, N., Brinckmann, J., Bausch, A., Is Innovation Always Beneficial? A Metaanalysis of the Relationship between Innovation and Performance in SMEs. "Journal of Business Venturing” Vol. 26 (4), pp. 441-457, 2011.

Schweizer, L., Concept and Evolution of Business Models, "Journal of General Management", 31(2), pp. 37-56, 2005.

Schinka, J. A., Velicer, W. F., Handbook of Psychology. Research Methods in Psychology, Hoboken, New Jersey, John Wiley \& Sons, Inc., 2003.

Shoham, A., Rose, G. M., Market Orientation: A Replication, Cross-national Comparison, and Extension, "Journal of Global Marketing" 14, 4, pp. 5-25, 2001.

Snoj, B., Milfelner, B., Gabrijan, V., The Examination of the Relationship among Market Orientation, Innovation Resources Reputational Resources and Company Performance in the Transitional Economy of Slovenia, "Canadian Journal of Administrative Sciences" Vol. 24, Issue 3, pp. 151-164, 2007.

Sparkes, A., Brychan, T., The Use of the Internet as a Critical Success Factor for the Marketing of Welsh Agri-food SMEs in the Twenty-first Century, "British Food Journal" 103(5), pp. 331-348, 2001. 
Strauss, J., Frost, R. D., Marketing on the Internet: Principles of on-line Marketing. Prentice Hall PTR, Upper Saddle River, NJ, USA, 1999.

Świadek, A., Spatial Proximity for Innovation Activity in Regional Industrial Systems in a Transition Country - Some Evidence from Empirical Research, "Argumenta Oeconomica", No 1 (24), pp. 165-190, 2010.

Tajeddini, K., Trueman, M., Larsen, G., Examining the Effect of Market Orientation on Innovativeness, "Journal of Marketing Management", 22, pp. 529-551, 2006.

Tomarken, A. J., Waller, N. G., Potential Problems with "Well-fitting” Models, "Journal of Abnormal Psychology", 112, pp. 578-598, 2003.

Walsh, G, Beatty, S. E., Shiu, E. M. K., The Customer-based Corporate Reputation Scale: Replication and Short Form, "Journal of Business Research", 62, pp. 924-930, 2009.

Zhou, K., Yim, C., Tse, D., The Effects of Strategic Orientations on Technology-and Marketbased Breakthrough Innovations, "Journal of Marketing”, 69, pp. 42-60, 2005.

Received: September 2014, revised: April 2017 